\title{
Investigating the Employment Profile of Graduate Students of Persian and English Literature
}

\author{
Behrooz Marzban \\ Ferdowsi University of Mashhad, Iran \\ Maliheh Yazdfazeli \\ Department of English Language Teaching, Torbat-e Heydarieh Branch, Islamic Azad University, Torbat-e Heydarieh, \\ Iran \\ Mina Ghodrati \\ Department of English Language Teaching, Torbat-e Heydarieh Branch, Islamic Azad University, Torbat-e Heydarieh, \\ Iran
}

\begin{abstract}
The issues of job and entrepreneurship have been always the concerns of students as well as every academic environment in Iran and other countries. University degrees are no longer sure fire formulas for high profile employment. The current study tries to investigate the employment rate of two university majors, namely Persian Literature and English Literature as a comparative analysis. A questionnaire was employed to investigate the related factors. Due to unavailability of the graduates, they were contacted via phone and asked to give their response to questionnaire items. The results of the study showed a big contrast between the two groups. English graduates have a good place in the Iranian labor market, while Persian graduates have a hard time finding employment.
\end{abstract}

Index Terms -Persian literature, English literature, entrepreneurship, TEFL, alumni, job, Iran

\section{INTRODUCTION}

There is no doubt that jobs have a pivotal role in the lives of people. Psychologists and Sociologists have stated that jobs help individuals structure their time, form identity and self respect, and be accepted as members of the society capable of making contributions (Roberts, Noble \& Duggan, 1982). Harmful effects of unemployment and underemployment have been pointed out in different lines of research (e.g. Bruwer, 1998).

Until recently, higher education used to guarantee professional success. However, this is no more the case. Nowadays, many university undergraduates and graduates are incapable of finding a job. And those who manage to find a job may resort to professions that are hardly related to their major field of study or may have to stoop to underemployment. Instances of highly educated people working as shopkeepers and secretaries are not very rare these days in Iran and other countries.

\section{REVIEW OF THE LITERATURE}

Our work is a practical study of graduate employment rates in Iran and as such it is a localized project. We couldn't find many works directly related to our project but the following studies are similar to our research and cast light on similar issues.

Cardoso and Ferreira (2002) tackled the issue of graduate unemployment and came up with findings that did not lend support to the popular notion that the rate of unemployment and underemployment of university graduates has made it too risky to continue education. The researchers used a longitudinal data set matching workers and their employers in the Portuguese private sector from 1986 to 1997. Analysis of the data revealed that the commonplace view that employers are no longer willing to recruit university graduates is a misleading one. The results of the study showed that although finding job opportunities had become difficult for Portuguese university graduates since 1990s, the rate of job creation had been increasing ever since.

Working along a similar line of research, Bruwer (1998) tried to investigate the impact of graduates' education on their job placement, job satisfaction, career advancement, earnings and intellectual development. He developed a detailed-structured questionnaire and sent it along with a self-addressed postage-paid envelope to a sample of 3208 alumni who had graduated from the Cape Technikon, a medium-sized higher education institution situated in Cape Town, South Africa. Bruwer found that 5.9\% of the institution's graduates were in unemployed occupational situation. However, the incidence of underemployment among the graduates was found to be much higher i.e. $40.2 \%$. He concluded that alumni unemployment or underemployment was a result of the mismatch between the ambitions of graduates and employment opportunities available to them. The researcher finally proposed that "an intermediate 
adjustment mechanism must be developed to relate the development of higher education to the development of the graduate employment market, and the expectations and attitudes of students" (p. 26).

Taking a somewhat different perspective, Nabi (2003) investigated the problem of graduate employability. He chose recent business graduates from a large higher education institution in the UK as his participants. A pack of questionnaires including an explanatory covering letter and reply-paid envelope were sent to the participants and responses were obtained from 203 graduates in full-time posts. The sample comprised 71 males and 132 females who had graduated 3.4 years ago, on the average. The findings of the study showed that underemployed university graduates tended to give a more negative picture of opportunities for skill use compared to their appropriately employed counterparts. As an important implication of his study, the researcher proposed that underemployed graduates should find opportunities to develop more skills that are related to their majors. It is also argued in this study that higher education should focus on the quality of employment rather than merely looking at the number of student who have found employment after graduation.

Focusing on Europe, Nunez and Livanos (2010) examined the effect of an academic degree on short and long-term unemployment. Their study also investigated the effect of 14 academic subjects and country-specific effects on unemployment which do not pertain to the topic of the present study and will not be discussed. Nunez and Livanos used data from the 2005 European Union's Labour Force Survey which is designed to obtain information related to market data in Europe. The data consisted of information on a total of half a million individuals from 15 member states of the European Union. Analysis of the data revealed that academic degrees improve the individuals' chances of both short and long-term employment; however the effect on avoiding long-term unemployment is more moderate.

Among Asian researchers, Bai (2006) focused on graduate unemployment conducting a study to investigate the historical and socio-economic conditions for China's project to raise the level of participation in higher education, and the resulting graduate unemployment. The main focus of the article was to establish whether large scale expansion of China's higher education sector (a project started in 1999) should continue. The researcher pointed out that although the achievements gained by expansion of higher education sector is undeniable, the increasing rate of graduate unemployment and its associated problems which are a result of the educational expansion should not be overlooked. The rapid expansion of higher education in this country could not serve the country as much as it was predicted because as Blaug, Layard, and Woodhall (1969) stated in their seminal work some 40 years ago "poor countries can have too much education, and the manpower shortage of yesterday can become the manpower surpluses of tomorrow" (p. 1).

In the Iranian context, Biabani (2003) tried to explore the causes of graduate unemployment in his study. He identified Iranian unemployment as a structural one defining it as a form of unemployment resulting from a mismatch between the sufficiently skilled workers seeking employment and demand in the labor market. Biabani argued that in the context of Iran, lack of cooperation between universities and governmental organizations, a high proportion of youth population, the increase in the participation of women in the labor market, the staying of the elderly in the labor market, and the incapability of the private sector in providing job opportunities for university graduates are among the causes of graduate unemployment in the country. The study also claims that in 1375 - 1380 the government, as the biggest employer of graduated workforce, acted inefficiently in providing job opportunities. The researcher proposed that the structure of the labor market should be reconsidered in Iran in such a way as to comply with theories of structural unemployment. This will help, the writer argued, overcome the mismatch between workforce demand and the number of university graduates.

In another Iranian study, Katooli and Rahmani (2005) tackled the issue of challenges facing the employment of university graduates in Iran. The researchers argued that lack of coordination between universities and government bodies has resulted in surplus university graduates. They claimed that lack of trustable statistics, lack of strategic views in government and private sectors, managerial incapability in determining demand for workforce based on development macro-strategies, lack of efficient mid-term and long-term plans, arbitrary selection of policies, and changing of designed programs after any changes in governmental bodies are among the factors contributing to the mismatch between workforce demand and the capacity of universities across the country. They proposed that the capacity of universities should be based on the demand for workforce. It is also argued that the contents taught in university majors should be revised so that skills required for related professions will be acquired in each major.

There seems to be a convergence of findings between the last two studies in the context of Iran which is also the focus of the present study. Although stating rather different issues as causes of graduate unemployment in Iran, They both refer to lack of coordination between universities and policy-making governmental organizations as a major factor contributing to the high rate of graduate unemployment in Iran.

According to Khayyat (2007), the rate of graduate unemployment in Iran amounts to a high $20 \%$ which is utterly unacceptable. Unfortunately, there are conflicting reports making it difficult to trust these numbers. However, a high rate of graduate unemployment in the country is undeniable. Research in this area has been limited and insufficient, and this calls for government-funded nation-wide studies that can help us deal with this crisis.

Although the issue of graduate employability is of utmost importance, there is a lack of research in this area in Iran. A thorough scrutiny of the list of theses written by graduates of social sciences was useless and no thesis related to the topic of our discussion was found. 


\section{Methodology}

In order to investigate the employment rate of the Persian and English graduates, we chose a sample of 230 English graduates and 160 Persian graduates. The English students were graduates of 1384 to 1387 and the Persian majors had graduated in 1384 to 1385 . We tried our best, but we could not balance the sample. Since we had to contact the participants through phone, we faced many problems. Some of the phone numbers were changed and we had to call different people to get the participants numbers. In some cases, we couldn't finally get a number.

The items on the questionnaire were answered by the participants on the phone. We also made further inquiries in order to add depth to our research. For example, when participants said that they had non-governmental jobs, we asked some of them what their jobs were so that we could analyze their career success more carefully. Finally the answers given to the items on the questionnaire were analyzed one by one.

\section{RESUltS AND DISCUSSION}

In this section, answers given to the questionnaires are analyzed one by one. Each table in this section presents the answers given to an item on the questionnaire by the two groups under study. Each table is then followed by our analysis of the related item on the questionnaire. Wherever necessary, we made further inquiries from the participants in order to add depth to our analysis. For the purpose of clarity, the items on the questionnaire were chosen as the title of the tables i.e. each table heading is actually an item on the questionnaire.

TABLE 1.

DID YOU HAVE A JOB WHILE YOU WERE A STUDENT?

\begin{tabular}{|lll|l|l|l|l|}
\hline Major field of study & & & Frequency & Percent & Valid Percent & Cumulative Percent \\
\hline English Literature & Valid & yes & 131 & 57.0 & 57.0 & 57.0 \\
& & no & 99 & 43.0 & 43.0 & 100.0 \\
& & Total & 230 & 100.0 & 100.0 & \\
\hline Persian Literature & Valid & yes & 19 & 11.9 & 11.9 & 11.9 \\
& & no & 141 & 88.1 & 88.1 & 100.0 \\
& Total & 160 & 100.0 & 100.0 & \\
\hline
\end{tabular}

A quick look at the table above shows us that English graduates mostly held a job while they were doing their B.A. This is in sharp contrast with the employment rate of the graduates of Persian Literature which didn't rise above $11.9 \%$. The high rate of employment among English graduates is related to the nature of the English major. English language provides a lot of job opportunities for graduates and non-graduates alike. Students majoring in English Literature had almost invariably studied English in language institutes for years before entering the university. This gave them a good chance of working in those institutes as language teachers and their admittance in a university only boosted that chance. However, Persian graduates had a difficult time finding any job because their major only allowed them to apply for a number of positions which were already occupied.

TABLE 2.

WAS THIS JOB GOVERNMENTAL OR NONGOVERNMENTAL?

\begin{tabular}{|lll|l|l|l|l|}
\hline Major field of study & & & Frequency & Percent & Valid Percent & Cumulative Percent \\
\hline English Literature & Valid & nongovernmental & 130 & 56.5 & 100.0 & \\
& Missing & System & 100 & 43.5 & 100.0 \\
& Total & & 230 & 100.0 & \\
\hline Persian Literature & Valid & nongovernmental & 19 & 11.9 & 100.0 & \\
& Missing & System & 141 & 88.1 & 100.0 \\
& Total & & 160 & 100.0 & \\
\hline
\end{tabular}

Table 2 shows that all the employed students in our sample only held non-governmental jobs. This is to be expected because English majors could always find employment as language teachers in language institutes and Persian majors had to turn to jobs unrelated to their field of study. English majors were mostly teaching at the same institutes they were studying at some time ago, while Persian majors had to stoop to underemployment because there was no need for teachers of Persian language anymore. This limited nature of the jobs held by students of may be interpreted as negative because their job opportunities were narrow and without scope. However, the high availability of this limited position may lessen the negativity of the narrow job opportunities, especially because university graduates are finding it increasingly difficult to find job opportunities even after graduation (e.g. graduates of Persian Literature). This problem is seen in many countries including industrial countries. 
TABLE 3

HOW MUCH DID THE JOB PAY?

\begin{tabular}{|c|c|c|c|c|c|c|}
\hline \multicolumn{3}{|l|}{ Major field of study } & \multirow{2}{*}{$\begin{array}{l}\text { Frequency } \\
32\end{array}$} & \multirow{2}{*}{\begin{tabular}{|l|} 
Percent \\
13.9
\end{tabular}} & \multirow{2}{*}{\begin{tabular}{|l} 
Valid Percent \\
24.8
\end{tabular}} & \multirow{2}{*}{\begin{tabular}{|l|} 
Cumulative Percent \\
24.8
\end{tabular}} \\
\hline English Literature & Valid & 100 & & & & \\
\hline & & 120 & 3 & 1.3 & 2.3 & 27.1 \\
\hline & & 150 & 8 & 3.5 & 6.2 & 33.3 \\
\hline & & 200 & 17 & 7.4 & 13.2 & 46.5 \\
\hline & & 250 & 13 & 5.7 & 10.1 & 56.6 \\
\hline & & 300 & 7 & 3.0 & 5.4 & 62.0 \\
\hline & & 350 & 1 & .4 & .8 & 62.8 \\
\hline & & 400 & 2 & .9 & 1.6 & 64.3 \\
\hline & & 50 & 3 & 1.3 & 2.3 & 66.7 \\
\hline & & 60 & 2 & .9 & 1.6 & 68.2 \\
\hline & & 70 & 4 & 1.7 & 3.1 & 71.3 \\
\hline & & 80 & 3 & 1.3 & 2.3 & 73.6 \\
\hline & & 90 & 2 & .9 & 1.6 & 75.2 \\
\hline & & insufficient & 31 & 13.5 & 24.0 & 99.2 \\
\hline & & very insufficient & 1 & .4 & .8 & 100.0 \\
\hline & & Total & 129 & 56.1 & 100.0 & \\
\hline & Missing & 0 & 101 & 43.9 & & \\
\hline & Total & & 230 & 100.0 & & \\
\hline \multirow[t]{10}{*}{ Persian Literature } & Valid & 100 & 7 & 4.4 & 36.8 & 36.8 \\
\hline & & 120 & 1 & .6 & 5.3 & 42.1 \\
\hline & & 50 & 1 & .6 & 5.3 & 47.4 \\
\hline & & 60 & 2 & 1.2 & 10.5 & 57.9 \\
\hline & & 70 & 4 & 2.5 & 21.1 & 78.9 \\
\hline & & 80 & 3 & 1.9 & 15.8 & 94.7 \\
\hline & & 90 & 1 & .6 & 5.3 & 100.0 \\
\hline & & Total & 19 & 11.9 & 100.0 & \\
\hline & Missing & 0 & 141 & 88.1 & & \\
\hline & Total & & 160 & 100.0 & & \\
\hline
\end{tabular}

The above table presents the rough incomes of the employed students in our sample. It should be noted that some of the students were unwilling to discuss their incomes specifically and only told us that their incomes were insufficient or very insufficient. $35.7 \%$ of the English majors reported their incomes to be low, insufficient or very insufficient, while most of the Persian majors (58\%) also reported their incomes to be low. You can see a significant difference here between the incomes of the two groups. Most of the Persian majors had a low income while a lower percentage of the English majors had the same range of salary. A higher percentage of Persian majors (36.8\% vs. 24.8\% of English majors) reported acceptable incomes, while good salaries belonged mostly to English majors (39.6\% vs. 5.3\% of Persian majors). These statistics show that students of English Literature major have a good place in the Iranian labor market, while students of Persian Literature have to accept jobs with lower incomes.

TABLE 4

DO YOU CURRENTLY HAVE A JOB?

\begin{tabular}{|lll|l|l|l|l|}
\hline Major field of study & & & Frequency & Percent & Valid Percent & Cumulative Percent \\
\hline English Literature & Valid & yes & 166 & 72.2 & 72.2 & 72.2 \\
& & no & 64 & 27.8 & 27.8 & 100.0 \\
& & Total & 230 & 100.0 & 100.0 & \\
\hline Persian Literature & Valid & yes & 55 & 34.4 & 34.4 & 34.4 \\
& & no & 105 & 65.6 & 65.6 & 100.0 \\
& Total & 160 & 100.0 & 100.0 & \\
\hline
\end{tabular}

The most dramatic difference between the two groups of Persian and English Literature graduates was seen in their employment rate after graduation. As you can see in the above table, English graduates enjoyed a high $72.2 \%$ 
employment rate after graduation, while only $34.4 \%$ of Persian literature graduates managed to find jobs. The remarkable employment rate for English literature graduates is a result of the high demand for English language teachers, while the low employment rate for graduates of Persian literature is caused by the lack of demand for teachers of Persian literature. Apart from teaching, there are only a few other positions available for graduates of Persian literature, while English graduates can seek employment as teachers, translators, correspondents, etc. another factor influencing the employment rate of the two groups is the previous experience of English graduates as learners of English in language institutes. This experience helps them with their employment, while graduates of Persian literature had no such experience and had a hard time finding a job related to their major field of study. Another important factor affecting these graduates' employment is their degree completion. For graduates of English literature, completion of degree increased their employment rate by $13.2 \%$ which is only modest. For graduates of Persian literature, degree completion increased their employment rate by $22.1 \%$ which is better than English graduates.

TABLE 6

IS THIS JOB GOVERNMENTAL OR NONGOVERNMENTAL?

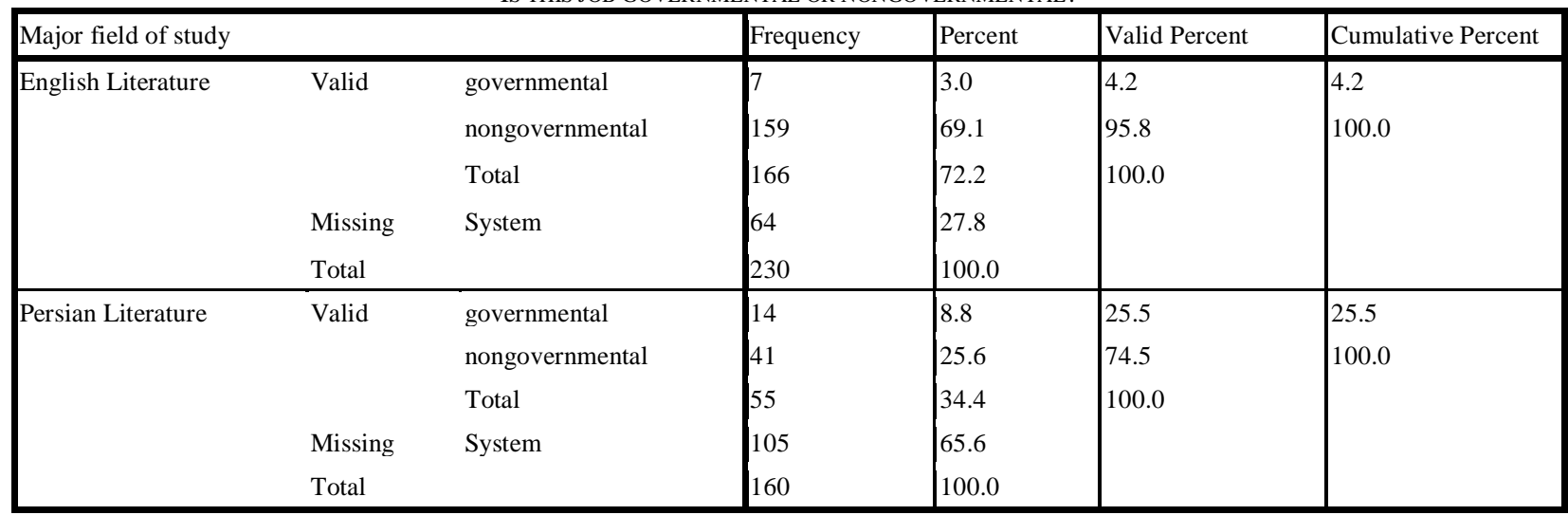

The above table shows that a big majority of the English literature graduates $(95.8 \%)$ and a majority of Persian literature graduates $(74.5 \%$ ) held non-governmental jobs. This is a result of the fact that all the governmental positions related to these majors were already filled. Because of this, Universities no longer guarantee employment as they used to before. Until some 10 or 12 years ago almost all graduates of both English and Persian literature had safe governmental jobs as language teachers in schools and universities. However, since higher education has recently become almost a must for everyone we are facing a high rate of universities graduates who have employment problems. Today, only graduates of Tarbiat-e Modarres universities can seek employment as school teachers. There aren't many other positions available for Persian literature graduates, but English graduates can seek employment as translators and they will not face a big vacancy problem. Only a small minority of the participants (3\% of English graduates and $8.8 \%$ of Persian graduates) reported that they had a governmental job. Some of these jobs were not even remotely related to their major field of study. 
TABLE 7

HOW MUCH DOES THE JOB PAY?

\begin{tabular}{|c|c|c|c|c|c|c|}
\hline \multicolumn{3}{|l|}{ Major field of study } & Frequency & Percent & Valid Percent & Cumulative Percent \\
\hline \multirow{21}{*}{ English Literature } & \multirow[t]{19}{*}{ Valid } & 100 & 9 & 3.9 & 5.5 & 5.5 \\
\hline & & 110 & 1 & .4 & .6 & 6.1 \\
\hline & & 120 & 4 & 1.7 & 2.5 & 8.6 \\
\hline & & 150 & 14 & 6.1 & 8.6 & 17.2 \\
\hline & & 200 & 14 & 6.1 & 8.6 & 25.8 \\
\hline & & 250 & 12 & 5.2 & 7.4 & 33.1 \\
\hline & & 300 & 27 & 11.7 & 16.6 & 49.7 \\
\hline & & 350 & 15 & 6.5 & 9.2 & 58.9 \\
\hline & & 400 & 27 & 11.7 & 16.6 & 75.5 \\
\hline & & 450 & 7 & 3.0 & 4.3 & 79.8 \\
\hline & & 50 & 1 & .4 & .6 & 80.4 \\
\hline & & 500 & 10 & 4.3 & 6.1 & 86.5 \\
\hline & & 550 & 2 & .9 & 1.2 & 87.7 \\
\hline & & 60 & 1 & .4 & .6 & 88.3 \\
\hline & & 600 & 8 & 3.5 & 4.9 & 93.3 \\
\hline & & 650 & 1 & .4 & .6 & 93.9 \\
\hline & & 700 & 1 & .4 & .6 & 94.5 \\
\hline & & insufficient & 9 & 3.9 & 5.5 & 100.0 \\
\hline & & Total & 163 & 70.9 & 100.0 & \\
\hline & Missing & 0 & 67 & 29.1 & & \\
\hline & Total & & 230 & 100.0 & & \\
\hline \multirow[t]{12}{*}{ Persian Literature } & \multirow[t]{10}{*}{ Valid } & 100 & 2 & 1.2 & 4.1 & 4.1 \\
\hline & & 150 & 6 & 3.8 & 12.2 & 16.3 \\
\hline & & 200 & 16 & 10.0 & 32.7 & 49.0 \\
\hline & & 250 & 6 & 3.8 & 12.2 & 61.2 \\
\hline & & 300 & 10 & 6.2 & 20.4 & 81.6 \\
\hline & & 350 & 1 & .6 & 2.0 & 83.7 \\
\hline & & 400 & 5 & 3.1 & 10.2 & 93.9 \\
\hline & & 450 & 2 & 1.2 & 4.1 & 98.0 \\
\hline & & 500 & 1 & .6 & 2.0 & 100.0 \\
\hline & & Total & 49 & 30.6 & 100.0 & \\
\hline & Missing & 0 & 111 & 69.4 & & \\
\hline & Total & & 160 & 100.0 & & \\
\hline
\end{tabular}

As you can see in the above table, there is a considerable increase in the income of the English graduates compared to their income while they were students. Persian literature graduates also saw a boost in their salaries. One of the reasons for this increase is degree completion. Obviously, both groups in our sample found many more positions available to them once they finished their studies. Another reason which mostly affected English graduates is their experience. As in any other jobs, the teaching profession requires experience. English graduates increased their experience while they were teaching as university students. All language institutes, as much as other organizations employing these graduates, value experience and increase their payments based on experience. However, the income increase after graduation was considered insubstantial by many graduates.

Especially Persian graduates many of whom were receiving small or very small salaries complained about their payments and lack of job opportunities. Although their biggest problem was finding employment, even those who did find a vacancy received very low salaries. Many of these graduates (Persian literature) believed that there were too many graduates in their field and this affected their employment rate. On the other hand, English graduates didn't have a hard time finding a job. Their salaries were also acceptable although some of them complained about their salaries and claimed that they needed to make more money. Some of the participants in our study (especially Persian graduates) claimed that they couldn't even think of marriage with the salaries they were receiving. 
TABLE 8

I LIKE MY JOB.

\begin{tabular}{|c|c|c|c|c|c|c|}
\hline \multicolumn{3}{|l|}{ Major field of study } & \multirow{2}{*}{$\begin{array}{l}\text { Frequency } \\
17\end{array}$} & \multirow{2}{*}{\begin{tabular}{|l} 
Percent \\
7.4
\end{tabular}} & \multirow{2}{*}{\begin{tabular}{|l} 
Valid Percent \\
10.2
\end{tabular}} & \multirow{2}{*}{\begin{tabular}{|l|} 
Cumulative Percent \\
10.2
\end{tabular}} \\
\hline English Literature & Valid & completely agree & & & & \\
\hline & & agree & 123 & 53.5 & 74.1 & 84.3 \\
\hline & & neither agree nor disagree & 21 & 9.1 & 12.7 & 97.0 \\
\hline & & diagree & 5 & 2.2 & 3.0 & 100.0 \\
\hline & & Total & 166 & 72.2 & 100.0 & \\
\hline & Missing & System & 64 & 27.8 & & \\
\hline & Total & & 230 & 100.0 & & \\
\hline Persian Literature & Valid & completely agree & 5 & 3.1 & 10.2 & 10.2 \\
\hline & & agree & 6 & 3.8 & 12.2 & 22.4 \\
\hline & & diagree & 27 & 16.9 & 55.1 & 77.6 \\
\hline & & completely disagree & 11 & 6.9 & 22.4 & 100.0 \\
\hline & & Total & 49 & 30.6 & 100.0 & \\
\hline & Missing & System & 111 & 69.4 & & \\
\hline & Total & & 160 & 100.0 & & \\
\hline
\end{tabular}

Table 8 presents the results related to item 7 in the questionnaire. As you can see, $84.3 \%$ of the English majors liked their jobs, while only $22.4 \%$ of Persian majors liked their jobs. This is a sharp contrast which is mostly a result of the relatedness of their jobs to their majors. Many Persian graduates had to seek employment as shopkeepers, taxi drivers, secretaries, etc. These are low profile jobs that even affect the graduates' self-respect. We cannot expect a taxi driver with a B.A in Persian literature to like his job. English graduates, on the other hand liked their jobs because they were related to their field of study and they enjoyed great popularity and respect as language teachers.

TABLE 9

MY JOB HAS MET MY EXPECTATIONS.

\begin{tabular}{|c|c|c|c|c|c|c|}
\hline \multicolumn{3}{|l|}{ Major field of study } & Frequency & Percent & Valid Percent & Cumulative Percent \\
\hline \multirow[t]{8}{*}{ English Literature } & Valid & completely agree & 2 & .9 & 1.2 & 1.2 \\
\hline & & agree & 82 & 35.7 & 49.7 & 50.9 \\
\hline & & neither agree nor disagree & 30 & 13.0 & 18.2 & 69.1 \\
\hline & & disagree & 50 & 21.7 & 30.3 & 99.4 \\
\hline & & completely disagree & 1 & .4 & .6 & 100.0 \\
\hline & & Total & 165 & 71.7 & 100.0 & \\
\hline & Missing & System & 65 & 28.3 & & \\
\hline & Total & & 230 & 100.0 & & \\
\hline \multirow[t]{7}{*}{ Persian Literature } & Valid & completely agree & 2 & 1.2 & 4.1 & 4.1 \\
\hline & & agree & 9 & 5.6 & 18.4 & 22.4 \\
\hline & & disagree & 26 & 16.2 & 53.1 & 75.5 \\
\hline & & completely disagree & 12 & 7.5 & 24.5 & 100.0 \\
\hline & & Total & 49 & 30.6 & 100.0 & \\
\hline & Missing & System & 111 & 69.4 & & \\
\hline & Total & & 160 & 100.0 & & \\
\hline
\end{tabular}

As you can see in table 5.8, 52.1\% of English graduates in our sample reported that their job expectations were met, while only $22.4 \%$ of Persian graduates claimed that their job expectations were met. Again, we see a big contrast which is rooted in the nature of the jobs held by our participants. Many of Persian graduates gave a negative response to this item because their job had nothing to do with their field of study. English graduates, on the other hand knew that they were going to become language teachers even before graduation. They knew their jobs and they knew what to expect of their jobs. Therefore, most of them saw in their jobs exactly what they expected. 
TABLE 10

MY JOB IS IN LINE WITH MY MAJOR.

\begin{tabular}{|c|c|c|c|c|c|c|}
\hline \multicolumn{3}{|l|}{ Major field of study } & Frequency & Percent & Valid Percent & Cumulative Percent \\
\hline \multirow[t]{9}{*}{ English Literature } & Valid & completely agree & 97 & 42.2 & 58.8 & 58.8 \\
\hline & & agree & 55 & 23.9 & 33.3 & 92.1 \\
\hline & & neither agree nor disagree & 2 & .9 & 1.2 & 93.3 \\
\hline & & disagree & 8 & 3.5 & 4.8 & 98.2 \\
\hline & & completely disagree & 2 & .9 & 1.2 & 99.4 \\
\hline & & 22 & 1 & .4 & .6 & 100.0 \\
\hline & & Total & 165 & 71.7 & 100.0 & \\
\hline & Missing & System & 65 & 28.3 & & \\
\hline & Total & & 230 & 100.0 & & \\
\hline \multirow[t]{7}{*}{ Persian Literature } & Valid & completely agree & 5 & 3.1 & 10.2 & 10.2 \\
\hline & & agree & 3 & 1.9 & 6.1 & 16.3 \\
\hline & & disagree & 27 & 16.9 & 55.1 & 71.4 \\
\hline & & completely disagree & 14 & 8.8 & 28.6 & 100.0 \\
\hline & & Total & 49 & 30.6 & 100.0 & \\
\hline & Missing & System & 111 & 69.4 & & \\
\hline & Total & & 160 & 100.0 & & \\
\hline
\end{tabular}

Table 10 shows that $92.1 \%$ of the English graduates either agreed or completely agreed that their jobs were in line with their major field of study, while only $16.3 \%$ of Persian literature graduates claimed that their jobs were related to their major field of study. This contrast can be explained by the lack of job opportunities for Persian graduates. As mentioned earlier, governmental teaching positions are already filled and Persian graduates have to seek employment in other places. Some of them had to become taxi drivers, secretaries, shopkeepers, etc. It is obvious that Persian literature as a major field of study cannot provide job opportunities in Iran. Surprisingly, many of these graduates claimed that they already knew this major could not provide them with a job. They claimed that the only reason for continuing their education in this field was getting a degree which is becoming increasingly important these days. Unlike, graduates of Persian literature, English literature graduates mostly found jobs related to their major.

TABLE 11

I RECEIVE A FAIR SALARY BASED ON MY WORKLOAD

\begin{tabular}{|c|c|c|c|c|c|c|}
\hline \multicolumn{3}{|l|}{ Major field of study } & \multirow{2}{*}{\begin{tabular}{|l} 
Frequency \\
40
\end{tabular}} & \multirow{2}{*}{\begin{tabular}{|l|} 
Percent \\
17.4
\end{tabular}} & \multirow{2}{*}{$\frac{\text { Valid Percent }}{24.1}$} & \multirow{2}{*}{\begin{tabular}{|l} 
Cumulative Percent \\
24.1
\end{tabular}} \\
\hline English Literature & Valid & agree & & & & \\
\hline & & neither agree nor disagree & 54 & 23.5 & 32.5 & 56.6 \\
\hline & & disagree & 66 & 28.7 & 39.8 & 96.4 \\
\hline & & completely disagree & 6 & 2.6 & 3.6 & 100.0 \\
\hline & & Total & 166 & 72.2 & 100.0 & \\
\hline & Missing & System & 64 & 27.8 & & \\
\hline & Total & & 230 & 100.0 & & \\
\hline \multirow[t]{7}{*}{ Persian Literature } & Valid & agree & 6 & 3.8 & 12.2 & 12.2 \\
\hline & & neither agree nor disagree & 5 & 3.1 & 10.2 & 22.4 \\
\hline & & disagree & 27 & 16.9 & 55.1 & 77.6 \\
\hline & & completely disagree & 11 & 6.9 & 22.4 & 100.0 \\
\hline & & Total & 49 & 30.6 & 100.0 & \\
\hline & Missing & System & 111 & 69.4 & & \\
\hline & Total & & 160 & 100.0 & & \\
\hline
\end{tabular}

Table shows that some of the English graduates (42.4\%) and most of the Persian graduates (77.5\%) in our sample didn't think they were receiving a fair salary based on their workload. It is not surprising that Persian graduates complain about their salaries. They usually work in areas unrelated to their field of study and requiring no expertise, so their salaries are low. However, since most English graduates work as professionals in the language teaching profession they are expected to receive a fair salary. On the contrary, these graduates are paid only modest salaries and have a right to complain. Language institutes are owned by individuals in the private sector who only think of their own profit. As a result, teachers receive low salaries. 
TABLE 12

I DON'T HAVE ECONOMIC PROBLEMS

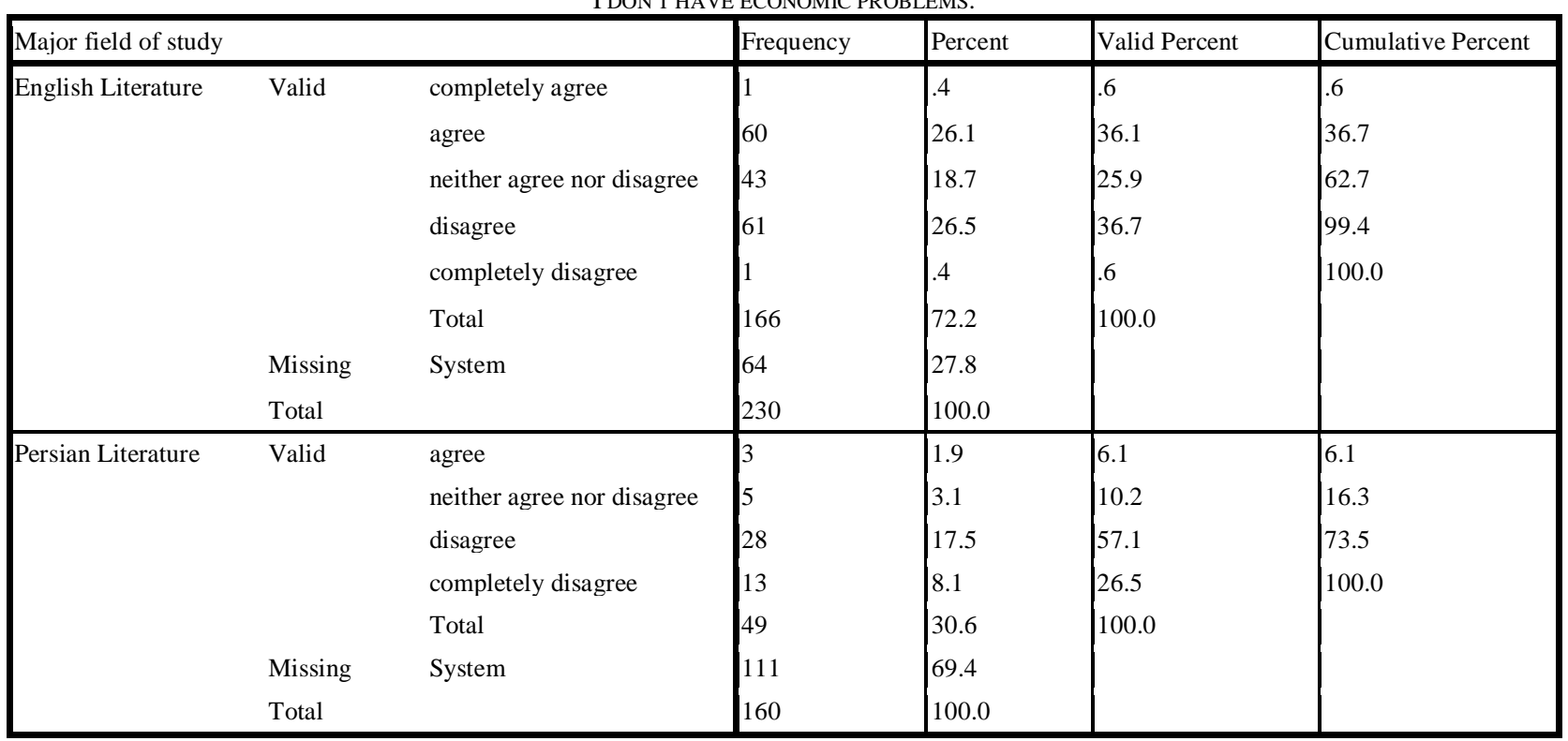

The above table presents the results related to item 11 in our questionnaire. This item is an inquiry about the participants' economic problems. As you can see in the table, 36.7\% of English graduates reported that they didn't have economic problems while only $16.3 \%$ of Persian graduates agreed with this item. The fact that a big majority of Persian graduates faced economic problems $(83.6 \%)$ is rooted in their employment problems. Since they have difficulty finding employment, they are expected to have economic problems. As for English graduates, although they did not have a difficult time finding their jobs, many of them received low salaries as indicated in table. Therefore, those who only worked as English language teachers and had no other source of income did face economic problems.

TABLE 13

I HAVE JOB SECURITY.

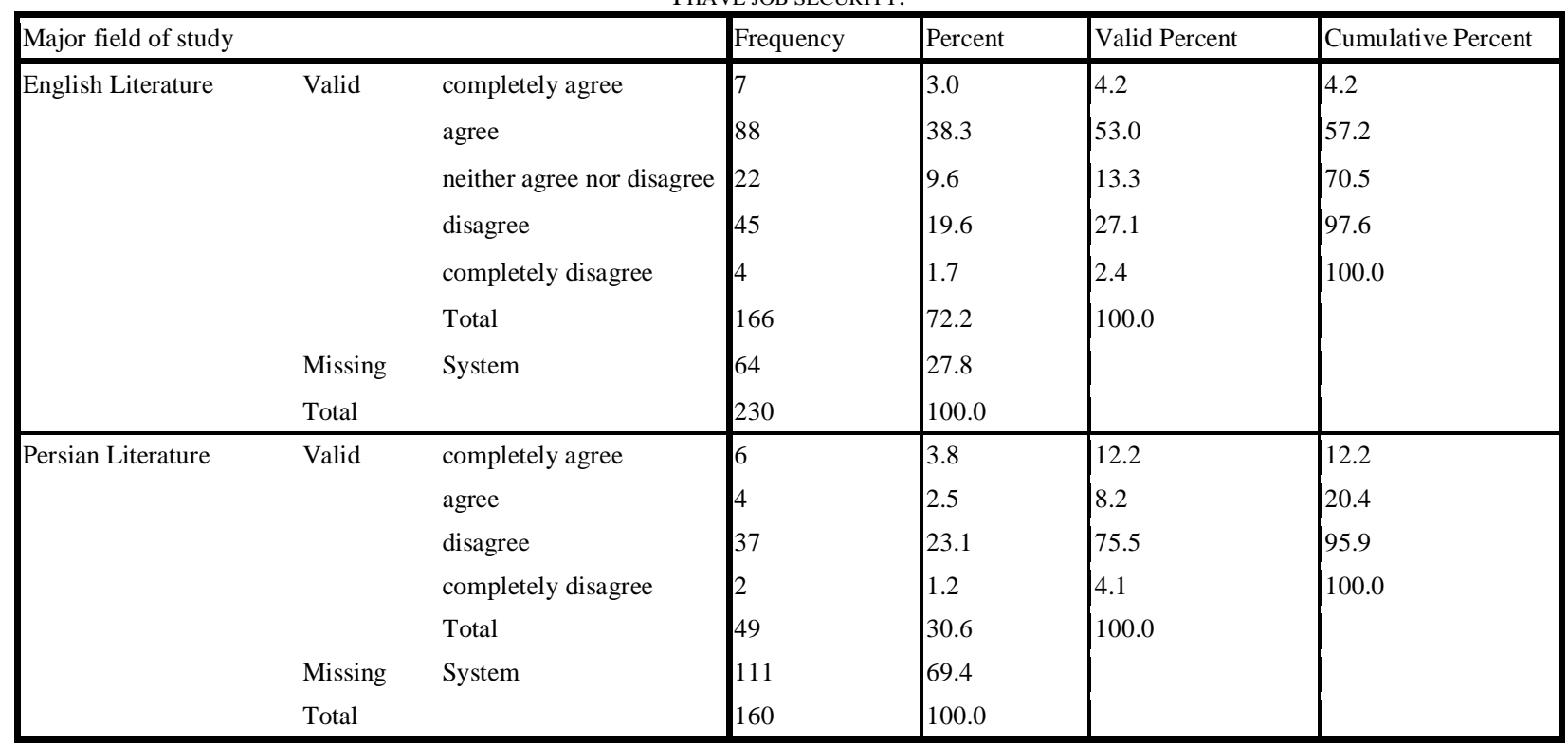

Table is related to item 12 in the questionnaire which inquires about participants' job security. As you can see, a majority of the English graduates $(57.2 \%$ ) reported that they had job security, while only $20.4 \%$ of Persian graduates enjoyed job security. English graduates are secure in their jobs, because they are hired as academically trained professionals and they will not be replaced easily. However, Persian graduates are insecure in their jobs because many of them had jobs unrelated to their field of study. Furthermore, many of them have jobs with unimpressive requirements. This makes them vulnerable and easily replaceable, so they feel insecure in their jobs. As for English graduates, those who do get fire or replaced for whatever reason will be able to seek employment elsewhere. Therefore, they feel secure in their jobs. 
TABLE 14

HOW LONG DID IT TAKE YOU TO FIND A JOB AFTER GRADUATION

\begin{tabular}{|c|c|c|c|c|c|c|}
\hline \multicolumn{3}{|l|}{ Major field of study } & Frequency & Percent & Valid Percent & Cumulative Percent \\
\hline \multirow[t]{7}{*}{ English Literature } & Valid & $1-3$ months & 120 & 52.2 & 72.3 & 72.3 \\
\hline & & 3-6 months & 32 & 13.9 & 19.3 & 91.6 \\
\hline & & 6-12 months & 12 & 5.2 & 7.2 & 98.8 \\
\hline & & more than 12 months & 2 & .9 & 1.2 & 100.0 \\
\hline & & Total & 166 & 72.2 & 100.0 & \\
\hline & Missing & System & 64 & 27.8 & & \\
\hline & Total & & 230 & 100.0 & & \\
\hline \multirow[t]{8}{*}{ Persian Literature } & Valid & $1-3$ months & 6 & 3.8 & 12.2 & 12.2 \\
\hline & & 3-6 months & 21 & 13.1 & 42.9 & 55.1 \\
\hline & & 6-12 months & 12 & 7.5 & 24.5 & 79.6 \\
\hline & & more than 12 months & 7 & 4.4 & 14.3 & 93.9 \\
\hline & & 5 & 3 & 1.9 & 6.1 & 100.0 \\
\hline & & Total & 49 & 30.6 & 100.0 & \\
\hline & Missing & System & 111 & 69.4 & & \\
\hline & Total & & 160 & 100.0 & & \\
\hline
\end{tabular}

As you can see in the above table, a majority of English graduates $(72.3 \%)$ had a job almost right after graduation (took them $1-3$ months or even less), while most of Persian graduates (81.7\%) had to look for their jobs for more than 3 months. The explanation for English graduates' success in this area is very simple. Many of them were already language teachers and the rest were easily hired as English language teachers because of their degree. Language institutes don't even require work experience as long as the individual has a good command of English. As for Persian graduates, they had to look for employment for a longer period of time because jobs requiring their expertise were already filled.

TABLE 15

IN YOUR OPINION, WHAT IS THE CAUSE OF GRADUATES' UNEMPLOYMENT?

\begin{tabular}{|c|c|c|c|c|c|c|}
\hline \multicolumn{3}{|l|}{ Major field of study } & Frequency & Percent & Valid Percent & Cumulative Percent \\
\hline \multirow[t]{5}{*}{ English Literature } & Valid & nonstandard Konkoor & 60 & 26.1 & 26.1 & 26.1 \\
\hline & & $\begin{array}{l}\text { not working on applied knowledge } \\
\text { at universities }\end{array}$ & 16 & 7.0 & 7.0 & 33.0 \\
\hline & & $\begin{array}{l}\text { lack of coordination between } \\
\text { universities and government } \\
\text { institutions }\end{array}$ & 61 & 26.5 & 26.5 & 59.6 \\
\hline & & $\begin{array}{l}\text { inefficient analysis of workforce } \\
\text { demand by organizations in charge }\end{array}$ & 93 & 40.4 & 40.4 & 100.0 \\
\hline & & Total & 230 & 100.0 & 100.0 & \\
\hline \multirow[t]{5}{*}{ Persian Literature } & Valid & nonstandard Konkoor & 39 & 24.4 & 24.4 & 24.4 \\
\hline & & $\begin{array}{l}\text { not working on applied knowledge } \\
\text { at universities }\end{array}$ & 23 & 14.4 & 14.4 & 38.8 \\
\hline & & $\begin{array}{l}\text { lack of coordination between } \\
\text { universities and government } \\
\text { institutions }\end{array}$ & 72 & 45.0 & 45.0 & 83.8 \\
\hline & & $\begin{array}{l}\text { inefficient analysis of workfrce } \\
\text { demand by organizations in charge }\end{array}$ & 26 & 16.2 & 16.2 & 100.0 \\
\hline & & Total & 160 & 100.0 & 100.0 & \\
\hline
\end{tabular}

Table 15 presents the results related to item 14 in the questionnaire which asked the participants about their opinions regarding the cause of graduates' unemployment. Five choices were provided based on the literature (Jahangir Biabani, 2003; Katooli and Rahmani, 2005) and the participants were asked to pick one of these causes.

$40.4 \%$ of the English graduates chose "inefficient analysis of workforce demand by organizations in charge" as the main cause of graduate unemployment in the country. The next highly picked cause for graduate unemployment by this group was "lack of coordination between universities and government institutions" with a percentage of $26.5 \%$ and a "non-standard Knokoor" was chosen by $26.1 \%$ of English graduates. Lack of emphasis on applied knowledge in universities was also chosen by $7 \%$ of the English majors as the main cause of graduate unemployment in Iran. 
In the case of Persian majors, a majority (45\%) of them chose lack of coordination between universities and government institutions as the main cause of graduate unemployment. $24.4 \%$ chose non-standard Konkoor (university entrance exam) as the main cause and $16.2 \%$ picked inefficient analysis of workforce demand as the main cause of graduate unemployment. Finally, lack of emphasis on applied knowledge in universities was chosen by the lowest percentage of Persian majors (14.4\%).

\section{CONCLUSION}

The present study tried to investigate the employment rate of university graduates in Iran. The students had all graduated in 1384-1388. The English sample was a little bigger mostly because of the availability of the participants in this group. These participants were not available in person because they had all graduated and we had to contact them through phone calls.

We used a questionnaire that was compiled from different questionnaires used in Job satisfaction studies. Unfortunately, we couldn't find studies quite similar to ours and this forced us to turn to job satisfaction studies.

The results of the study revealed that English literature graduates have a high employment rate in Iran, while Persian literature graduates had a low rate of employment. Even those Persian graduates who did manage to find a job, did so by accepting underemployment. Some of them became taxi drivers, shopkeepers, secretaries, etc. English graduates, on the other hand, could always find employment as teachers in language institutes. English is a universal language which is much in vogue anywhere in the world. Many people in Iran want to learn English and this has led to the burgeoning of English language institutes. As a result, anyone with a command of English can easily find a job as English language teacher. The fact that our participants held a university degree in this field only increased their chances of employment.

The sharp contrast in the employment rate of these two groups (English vs. Persian graduates) is very alarming. Authorities should find ways of improving the employment opportunities of Persian graduates and many other university graduates who have to stoop to underemployment. Another way to avoid underemployment is careful choosing of university majors. Those of us who do have a choice in our field of study should consider our future jobs when making this choice.

We also dealt with lack of job opportunities in Iran although very briefly. Several reasons for this lack of employment were investigated. The participants in our study chose two main reasons for graduate unemployment. The first one is lack of coordination between universities and governmental institutions. The second reason is inefficient analysis of workforce demand by organizations in charge. Two other reasons were also identified for graduate unemployment but they were only chosen by a minority of participants.

Thorough investigation of the reasons behind lack of job opportunities in Iran has to be done in a separate research project with much more time and resources than available to us. This is an under-researched area which needs particular attention because of its critical importance. University degree was once a gem not available to everyone. Nowadays, it is abundant and losing value. A higher rate of highly educated individuals in the country is desirable, but big problems arise when these highly educated individuals find it difficult to get a job.

\section{REFERENCES}

[1] BAI, L. M. (2006). Graduate unemployment: dilemmas and challenges in China's move to mass higher education. The China Quarterly, 185, 128-144.

[2] Biabani, J. (2003). Unemployment of university graduates and structural unemployment, Imam Sadeq University Research Quarterly, 20. Retrieved April 15, 2010, from http://www.hawzah.net/Per/Magazine/IS/020/IS02001.asp.

[3] Blaug, M., Layard, R., \& Woodhall, M. (1969). The causes of graduate unemployment in India. London: Allen Lane the Penguin Press.

[4] Bruwer, J. (1998). First destination graduate employment as key performance indicator: Outcomes assessment perspectives. Melbourne, Australia: Paper presented at Australian Australasian Association for Institutional Research (AAIR) Annual Forum.

[5] Cardoso, A. R., \& Ferreira, P. (2001). The dynamics of job creation and destruction for University graduates: why a rising unemployment rate can be misleading [Discussion paper]. Forschungsinstitut zur Zukunft der Arbeit Institute for the Study of Labor.

[6] Fan, C. S., \& Stark, O. (2007). The brain drain, educated unemployment, human capital formation, and economic betterment. The Economics of Transition, 15 (4), 629-660.

[7] Katooli, A. N., \& Rahmani, R. (2005). Challenges facing the employment of university graduates, Tadbir Monthly, 153. Retrieved April 18, 2010, from http://imi.ir/tadbir/tadbir-153/article-153/5.asp.

[8] Khayyat, A. H. (2007). A study of the causes of graduate unemployment in the city of Marand. Retrieved April 2, 2010, from http://www.jobportal.ir/S1/Default.aspx?ID=9_2_3637_1_401.

[9] Nabi, G. R. (2003). Graduate employment and underemployment: opportunity for skill use and career experiences amongst recent business graduates. Education + Training, 45 (7), 371-82.

[10] Nunez, I., \& Livanos, I. (2010). Higher education and unemployment in Europe: An analysis of the academic subject and national effects. Higher Education 59 (4), 475-487.

[11] Roberts, K., Noble, M., \& Duggan, J. (1982). Youth Unemployment: An Old Problem or a New Lifestyle? Leisure Studies, 1, 171-182. 
Behrooz Marzban has an MA degree from Ferdowsi University of Mashhad, Iran.

Maliheh Yazdfazeli has an MA from Department of English Language Teaching, Torbat-e Heydarieh Branch, Islamic Azad University, Torbat-e Heydarieh, Iran.

Mina Ghodrati has an MA from Department of English Language Teaching, Torbat-e Heydarieh Branch, Islamic Azad University, Torbat e Heydarieh, Iran. 